\title{
消費者教育としての保険教育
}

損保協会の取組みを通して考える

\section{竹 井 直 樹}

\section{ロアブストラクト}

消費者向けの保険教育については，これまで，損保協会が保険の仕組みや 商品に関する各種情報提供, 高校, 大学への講師派遣, 消費生活相談員向け 勉強会などの取組みを行ってきた。また，最近，「消費者教育の推進に関す る法律」が施行され文部科学省や金融庁でもその後押しの取組みがさまざま に行われている。しかし, 保険の専門性や複雑性から, 教える側と学ぶ側の 意識や知識差の違いを克服するのはそう簡単ではない状況にある。そこで, そもそも消費者教育の主体・客体という構図をリセットし，消費者側と事業 者側が一体になった関係のなかで，新たな消費者教育を構築していく必要が ある。保険商品のシンプル化，わかりやすさを大前提にして，消費者とのコ ミュニケーション機会をさらに増やしながらお互いが学びあうという発想の 転換が不可欠である。また，学校教育（特に大学の連続講座）の場は，リス ク教育を含めて損害保険が持つ学究性と実利性の双方を学ぶ格好の機会であ る。

\section{ロキーワード}

消費者教育，保険教育，損保協会

/ 平成 25 年 9 月 30 日原稿受領。 


\section{1.はじめに}

日本損害保険協会（以下「損保協会」という。）に身を置いて38年が経過 した。業界団体だから，日々，おおよそは業界の視点で物事を考えてきた。 業界の視点は，業界共通の利害事項を業界団体として共有していくプロセス のなかで形成され，業界の考え方（以下「業界認識」という。）として表面 化する。業界認識は，その多くは個々の会員会社の利害を調整することによ って導かれるが，時には業界団体が独自に会員会社を牽引，誘導して築かれ る場合もある。後者の場合は業界団体が会員会社を説得することになる。

いずれにしても，業界認識は，目に見えない，不特定多数の「世間感覚」 という漠とした価値観にさらされる。「世間感覚」は一般的には消費者（層）, 時として消費者の声を代弁するといわれるマスメディアが作り上げる（以下 これを「消費者感覚」という。)。消費者感覚とはそうした漠としたものであ るから，その消費者に対する保険教育となると，これは一筋縄にはいかない。 なぜなら，そもそも消費者感覚とは何かを把握すること自体が容易ではない から，その教育はなおさら混沌としている。したがって，消費者教育の出発 点は，消費者とは何か，消費者感覚とは何か，消費者は何を理解し，何を理 解していないのかなどを根気よく把握することである。これは，換言すれば 業界認識と消費者感覚の溝を丁寧に地道に，少しずつ埋めていく取組みであ るといえる。

本稿では，消費者に対する保険教育の意義・必要性とその主体は誰なのか， そして保険教育における論点は何かを，損保協会がこれまで消費者層に対し てどのように向き合ってきたのかを振り返りながら，また，2012年12月に施 行された「消費者教育の推進に関する法律」(以下「推進法」という。) ${ }^{1)}$

1）この法律は，消費者教育の機会が与えられることが消費者の権利であること を明らかにし，基本方針と国㧍よび自治体の責務を定め，消費者教育の総合的， 一体的な推進を図ることを目的として制定された。所管官庁は消費者庁である。 
2013年 4 月に公表された「金融経済教育研究会報告書」 ${ }^{2)}$ (以下「金融庁報 告書」という。）にも触れながら，私の思うところを述べたい。

\section{2. 損害保険というもの}

筆者の実務経験からは「保険はむずかしい」の一言に尽きる。保険商品と 他の一般的な商品との違いを簡単に表せば，目に見えないので手にとって効 能を確認できない，そしてその効能は起こるかもしれない，起こらないかも しれない保険事故の発現によってごく一部の人だけに実感され ${ }^{3)}$ また，保 険約款を見ればわかるように当事者が守らなければならない約束事があまり にも多いなどの特徵がある。取引プロセスでも, 商品購入時, 契約途中, 保 険事故発生時にはさまざまな手続きが必要になる。したがって，損害保険に 携わる以上は，「保険はむずかしい」ということを源点に据えて，さまざま な場面に対応しなければならない。そうするとビジネスモデルにおいて常に 意識すべきは自ずと「シンプル化」「「かりやすさ」にならざるを得ない。

1996年に施行された保険業法の全面改正は，保険自由化の幕開けとなり， それまでの業界横並び体質を一変させた。商品も料率も自由化が飛躍的に進 み，各損害保険会社（以下，特に断り書きのないかぎり「損害保険会社」を 単に「保険会社」という。）がそれぞれ独自商品を販売するようになった。 特に普通保険約款の補償範囲を拡大する特約やリスクの減少を評価したさま ざまな割引の競争が激しく行われた。こうした競争は保険を利用する者にと

2） 2012年11月に金融庁金融研究センターに設置された「金融経済教育研究会」 がまとめた報告書。研究会のメンバーは有識者, 関係省庁, 金融業界団体で構 成され，今後の金融経済教育の進め方について，知識の習得に加えて判断力を 重視した「金融リテラシー」を明確化し, その向上を眓るための考え方をまと めた。

3）この説明には異論もあるかもしれない。損害保険には安心を確保する（リス クを引き受けてもらう）という機能があり，幸い事故が起こらなかった人には 効能はない（損をした）という考え方は正しくないというものである。正論で あり，まさにこれが保険教育の出発点であるといっても過言ではない。また， このことは保険教育がリスク教育と表裏一体であることも示している。 
消費者教育としての保険教育

っては欲しい商品が廉価に買えるという利便性の向上に大きく貢献したが， 一方で，各保険商品のさらなる複雑化を招いた。

保険商品の複雑化は，二つの意味を持っている。一つは保険を販売する側 の保険会社と保険代理店がその複雑化についていけず，商品説明がおろそか になるという問題（これは保険会社社員や代理店に対する保険教育の問題で あり，本稿ではこれ以上言及しない。）。もう一つは購入する側の消費者が， 販売する側の資質不足もあって，なおさら商品の理解がおぼつかないという 問題である。その結果は保険金の不払いや保険料の取り過ぎ問題（以下「保 険金不払問題」という。）となって世間を騒がせた。

また，近年の保険商品の構造として，総合保険化（組み合わせ化）がある。 損害保険は大別すると物保険, 責任保険, 費用保険, そして利益保険 ${ }^{4)}$ があ るが，火災保険，自動車保険，さらに海外旅行保険など，保険会社が扱う主 力商品は，これらを組み合わせたものが多い。消費者にとってはいろいろな 事故に対応してくれるので安心というメリットはあるが，物保険，責任保険 および費用保険はそれぞれ独自に発展してきた経緯があり，それぞれに商品 上の特徵がある。さらには，それぞれにさまざまな特約が付いているので， 総合保険の商品説明は情報量が多い分, 複雑になるし, したがって，わかり やすい商品説明の工夫もいっそう必要になる。

\section{3 . 損保協会と消費者の接点}

\section{(1) 初 期}

前述した保険商品の特徵からすれば，消費者側からの疑問や質問などの問 い合わせは当然多いことが予想される。損害保険業界（以下「損保業界」と

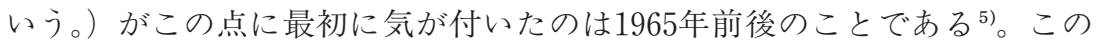

4）個人向けの保険では利益保険はないので，以下では利益保険には言及しない。

5）竹井直樹「損害保険に係る相談と苦情・紛争解決に関する考察一損保 ADR 序説とサステナビリティー一」大谷孝一博士古稀記念『保険学保険法学の課題 と展望』120頁～122頁（成文堂，2011年） 
経緯については拙稿に謹ることとするが，当時の保険審議会の答申 ${ }^{6)}$ を受け て，1965年 8 月に損保協会の本部内に「損害保険相談室」が新設され，地方 組織でも相談対応体制を整え，合わせて苦情処理機関として「損害保険調停 委員会」7)が設けられた。これと同じころに各保険会社にもそれぞれ相談空 ロが設けられたと思われる。このように損保業界が本格的に消費者と向き合 うようになったのは，この保険審議会答申が寄与している。当時としては相 談空口を設けること自体が画期的であっただろうが，損害保険の大衆化の流 れのなかでは，ごく自然な動きであり，相談，そして苦情の対応を通して損 害保険に対する消費者の理解や認識を肌で感じるようになったはずである。

消費者との接点を，相談・苦情空口を通じて各保険会社と損保協会が持つ ようになった意義はきわめて大きいと思う。それは，保険会社にとっては保 険販売上，一般的には消費者と直接接することがないから，消費者の生の声 が聴けることは貴重であるということ委，そして損保協会にとっては相談・ 苦情対応が業界団体事業の大きなミッションになりうるということである。 特に後者については，現在は，いわゆる金融 $\mathrm{ADR}$ 制度として，業界団体の 存在意義を左右しかねない一大事業となっている。

\section{(2) 発展期}

損保業界が自動車保険を中心に飛躍的な発展を遂げたなかで，消費者との

6） 1965年 3 月にまとめられた保険審議会の答申「損害保険募集機構の改善」。 なお，保険審議会は1959年に保険制度や保険行政の問題を検討する目的で当時 の大蔵大臣の私的諮問機関として設置された。その後, 保険審議会は1998年に 金融審議会へ統合された。

7）損害保険調停委員会は，今でいうADR (Alternative Dispute Resolution の略称で, 裁判外紛争解決手続を行う機関) であり, 当時としては画期的であ ったが，長年，取扱実績がないまま推移した。その後，2000年に組織が見直さ れ，少しずつ実績が増えていった。

8）代理店販売が中心の保険会社にとっては，通常，消費者の声は代理店に聞か なければわからないから, 消費者との距離は構造上遠いという認識を持つこと が必要不可欠である。 
消費者教育としての保険教育

接点は相談・苦情の対応を中心に行われてきたが9), これらの情報が業界全 体で共有され，ビジネスモデルの改善に積極的に活用されてきたかというと そうではなかった。この時代は残念ながら相談・苦情が宝の山であるという 発想はあまりなく，敗戦処理的な捉え方であったと考えられる。

一方，交通事故が激増するなかで，1960年代後半から損保協会が交通事故 防止や交通事故責任に対する啓発，周知の活動を行うようになった。マスメ ディア広告やマスメディアとタイアップしたイベントが主だったようである が，各消費生活センターとの懇談も実施されるようになって，交通事故だけ ではなく，防火，防災，そして損害保険知識の普及という観点でもさまざま な広報活動や周知活動を展開した ${ }^{10)}$ 。

もう一つ，保険教育という点では特筆すべき動きが始まった。それは損保 協会と各都道府県単位の消費生活センターとの懇談会や同センターで消費者 からの相談・苦情を直接受け付ける消費生活相談員（以下「相談員」とい う。）向けの損害保険勉強会等の開催である ${ }^{11)}$ 。1970年ごろから始まり，し ばらくはそれほど開催頻度は高くなかったようだが，その後1990年代になっ てからは県単位を中心に頻繁に行われるようになった。消費者への保険教育 を考える場合，「消費者講座」と銘打って一般消費者を直接集めて行うこと も不可能ではないが，とりあえず，消費者感覚を肌で感じている相談員に理 解を深めてもらうことは有益である。損保協会にとっては募集手続上効率的 であるし，まったくの保険素人ではないという点で，保険の理解促進には効

9） 1965年11月からは全社統一の「交通事故相談所」が全国約 2,100 か所の各保 険会社悹口が設けられたが，その後，1972年には自動車保険料率算定会（当 時）が設けていた自賠責保険請求相談室と統統合して，損保協会において全国 54か所の「自動車保険請求相談センター」が設置された。損保協会編『日本損 害保険協会70年史』348頁，480頁～482頁（損保協会，1989年)。なお，損害保 険に関する相談・苦情は契約者などの顧客からのものとは限らない。自動車保 険では加害者である被保険者の相手側である被害者からの相談・苦情が圧倒的 多く，この点が一般のケースと大いに異なるところである。

10）損保協会編・前掲（注 9）458頁～471頁。

11）損保協会編・前掲（注 9）459頁～460頁。 
果的であるといえる。そして，相談員が一定の保険知識を身に付けてもらえ れば，相談員が相談者へ説明することによって問題解決が図られ，巷に保険 知識が伝播しやすくなり，さらに保険会社への問い合わせや苦情が相対的に 減少する効果も期待できる。

ただし，相談員は，我々には想像もできないくらい多種多様な相談を受け ており，そのなかで損害保険を学ばうとするインセンティブが高いとは考え にくい。せめて金融分野に興味を持ってもらえる相談員が増えれば，損害保 険, 生命保険, 預金, 有価証券などの仕組みや役割の基本的な違いを学ぶこ とによって，入り口部分の金融知識レベルは格段に上がる可能性がある ${ }^{12)}$

\section{（3）最近の主な動き}

この10年ほどの損保業界の動きを消費者視点からみれば，大きな動きは何 といっても2005年から2006年にかけて発生した保険金不払問題であろう ${ }^{13)}$ ここでこの問題に詳しく言及するつもりはないが，この問題の背景を押えて おくことは，保険教育の考察にあたってはきわめて重要である。それは業界 認識と消費者感覚のズレである。保険自由化によって保険会社間の競争が激 化し，商品の差別化や優位性の競争が「保険はむずかいしい」という「定 理」を蹂躙し，「保険はますますむずかしい」という領域へ踏み入れてしま つた。

この問題を解決するために，2006年 9 月，損保協会は消費者の声を真摰に 聞き，業界全体の業務運営に反映させるべく，「消費者の声」諮問会議を設 置した。メンバーには消費者団体役員，民法・消費者法学者，経済学者，そ れに損保協会会長など業界委員が加わった。ここでまとめられた提言に基づ き，保険販売については，保険代理店の資質向上に向けた代理店試験の抜本

12）金融分野では，相談員有志が集まって自主的な勉強会を推進するグループも 散見される。

13）この問題の簡単な評釈は，竹井直樹「損害保険の市場と損害保険会社の経 営」大谷孝一・中出哲・平澤敦編『はじめて学ぶ損害保険』119頁～ 120 頁（有 斐閣，2012年）参照。 
消費者教育としての保険教育

的見直しを，また，商品や販売ツールについては，用語の平易化やわかりや すさの向上に向けた業界ガイドラインの作成などを行った。また，消費者教 育という観点では，損害保険の契約にあたって，最低限留意してもらいたい ことを，わかりやすく，簡単にまとめた「損害保険の契約にあたっての手引 き(バイヤーズガイド)」(以下「バイヤーズガイド」という。） ${ }^{14}$ をを消費者 への情報提供ツールとして各方面へ配布し，また，相談員の団体および金融 庁とタイアップして全国でバイヤーズガイド周知の学習会を開催した。もち ろん, 損保協会のホームページでは以前から一般消費者向けの情報提供とし て，損害保険商品の基本的な事項をはじめとしてさまざまな情報を掲示して きたが，バイヤーズガイドも消費者自身がプリントアウトできるコンパクト な分量の情報として掲載した。

\section{4. 損保協会が行う学校教育}

\section{(1) 高等学校教育}

沿革的には，損保協会にとって保険教育と学校教育は同義であったようだ。 ただし，高等学校向け教育が中心であり，損保協会が学習指導要領へ損害保 険を取り入れるよう文部省（当時）へ要望書を最初に提出したのは1960年の ことである。その後1963年には高校生を対象にして，損害保険作文コンクー ルが行われるようになり，同時に商業高等学校の高校生を対象に損害保険講 演会が始まった。また，高等学校の社会科・商業科の教師向けに損害保険に 関する副教材を作成した ${ }^{15)}$ 。こうした取組みは，次代を担う高校生に対し，

14）発端は，2005年，金融庁に「保険商品の販売勧誘のあり方に関する検討チ一 ム」が設置され，その中間論点整理のなかで，消費者への啓発活動として，業 界共通の「購入者手引」の作成が有効であると指摘されたことによる。生命保 険業界でも同様のものが作成された。なお，損保協会独自の取組みとしては， 若年社会人に向けに「フレッシャーズガイド」, 高齢者向けに「知っ得! ガイ ド」が保険啓発のためツールとして作成された。

15）損保協会編・前掲（注 9 ）337頁～340頁。なお，「高等学校学習指導要領」 については，その見直しを行った 2009 年 3 月の文部科学省告示に基づいて「高 等学校学習指導要領解説」が公表され, 「家庭科」の「家庭基礎」のなかで 
損害保険の知識を普及させ，自助努力の精神を養うことが目的だった。

これらの事業はその後，紆余曲折を経て，この10年ほどの間に縮小し，現 在は，学校の教師向けに損害保険をテーマにした「授業実践プログラム」16) を作成して授業を支援する取組みや学校からの依頼に基づく講師派遣の取組 みが行われている。

\section{(2) 大学教育}

大学教育については，従来から損保協会の事業の一環として，大学や大学 教員の依頼に基づき講師を派遣して講座の 1 コマ程度の講演を行う例は多々 あった。しかし，損保協会が大学を通じて体系的に保険教育に取り組んだの は2002年に始まった大分大学経済学部の損保協会寄附講座「損害保険事業の 概要と今後の課題・展望」からである。これは，当時，同大学で教鞭をとら れていた保険学者を介して実現したものであるが 2 年で終了した。その後, 2007年に琉球大学で損保協会の寄附講座「損害保険概論」が始まった。これ は沖縄県のみを事業範囲とする大同火災海上保険株式会社の尽力があって実 現した。この講座は対象学部を限定していないため, 文系・理系双方の学生 が受講しているので一般教養的な講座となっている。

そして，2010年から損保協会の地方組織である支部を通じて損害保険の大 学教育を全国的に推進するようになった。これは，損保協会の大きなミッシ ヨンである損害保険の理解促進活動のなかで，大学の寄附講座における保険 教育を組織的に展開することが機関決定されたことによる。特に，損害保険 を体系的に学べる機会が少ない地方の国立大学を中心に2013年12月現在，下 記の寄附講座が開講されている ${ }^{17,18)}$

「保険」がリスク管理の手段としてはじめて記載された。

16）この事業は2010年度から始まり，実績は2010年度が32校，2011年度が59校， 2012年度は171校にのぼり，着実に増えている。講師派遣については2010年度 が49校，2011年度が47校，2012年度が73校であった。

17）講師陣は損保協会の職員が中心であるが，一部に損保協会会員会社の社員や 日本損害保険代理業協会（プロ代理店の同業団体）の幹部にも担当願い，損保 


\begin{tabular}{|c|c|}
\hline 大 学 名・講 座 名 & 講座の期間 \\
\hline 北海道大学法学部「損害保険の実務と法」 & 上半期 \\
\hline 東北大学経済学部「損害保険概論」 & 夏季集中講座 \\
\hline 福島大学経済経営学類「リスクマネジメント」 & 下半期 \\
\hline 埼玉大学経済学部「損害保険概論」 & 下半期 \\
\hline 一橋大学「損害保険の法と実務」 & 上半期 \\
\hline 静岡県立大学「リスクマネジメント」 & 上半期 \\
\hline 中京大学法学部「損害保険の実務と法」 & 下半期 \\
\hline 金沢大学「現代社会における保険の制度と役割」 & 下半期 \\
\hline 関西大学政策創造学部「損害保険概論」 & 下半期 \\
\hline 広島大学経済学部「特別講義（保険論）」 & 上半期 \\
\hline 山口大学経済学部「特殊講義 I （日本損害保険協会）」 & 下半期 \\
\hline 香川大学法学部「損害保険の実務と法」 & 上半期 \\
\hline 徳島大学「損害保険の実務から学ぶ」 & 上半期 \\
\hline 高知大学人文学部「損害保険の実務と法」 & 下半期 \\
\hline 長崎大学経済学部「金融機関経営戦略」 & 上半期 \\
\hline 琉球大学「損害保険概論」 & 上半期・下半期 \\
\hline 名古屋大学法学部（2014年度から） & 夏季集中講座 \\
\hline 大阪大学法学部（2014年度から） & 未定 \\
\hline
\end{tabular}

*このほかでも，保険会社 OB などの実務家が非常勤講師を勤めている大学の保 険関係の講座としては，筆者が担当している講座を含め, 成城大学経済学部 $\ulcorner$ 保険論」, 高崎商科大学商学部「保険論」, 千葉商科大学商経学部「保険論 $\lrcorner$, 専修大学商学部「損害保険論」, 神奈川大学経営学部「損害保険概論」, 立命館 大学経済学部「保険経済論」などがある。

業界をあげた取組みにしている。なお，学部の記載のない大学は，学部を問わ ず受講できる講座である。

18）従来から損保協会では，単発講座でも寄附講座でも，受講学生にアンケート を記入してもらい，授業に対する評価を検証している。もっとも多い反応の概 略例としては，「交通事故をはじめとした災害に対する実践的な知識が身につ いた。リスクに対する認識が高まった」，「一口に保険といってもいろいろな種 類の保険があることに驚いた。損保と生保の違いすら分かっていなかったので 有益だった」などがある。一方，「内容が難しかった」あるいは「提供される 情報量が多すぎて，何をポイントに勉強したらよいのかわからない」といった 感想もときどき寄せられる。 
もともと保険には伝統的な学究の世界があり, 法学系では保険法, 海商法, 保険業法など, 商学系・経営系・経済系では保険論, 保険学あるいはリスク マネジメントなどの講座名で開講している。教員は保険学者などの主として 常勤の研究者が中心であるが，保険会社社員，OB などの非常勤の実務家も 一定程度携わっている。こうしてみると, 保険教育というジャンルはその専 門性ゆえに大学教育には馴染みやすい分野であるといえ, 理論教育と実務教 育の双方が学べる貴重な学習機会を提供できるのではないかと思う。

損害保険という分野に限っていえば，学生が保険消費者（保険購入者）で あるとは一概にはいえないが，消費者予備軍であることには間違いない。一 方, 地方の大学では散見されるが, 自動車や原付バイクで通学する学生は正 真正銘の保険消費者である。また，マンションやアパートを賃借する学生， 海外旅行をする学生も保険消費者である。リスクや損失負担の問題を, 大学 教育のなかで基礎から学ぶ意義はきわめて大きいし，これに理論的な観点も 加えながら学習していけば，理論と実務を兼ね備えた，まさに「生きる力」 を育む学校教育を実現できる。もちろん教え方は重要である。実務家なら誰 でもできるというものではない。筆者の経験からはスペシャリストよりはジ エネラリストの方が向いているように思う。

\section{5.リスク教育}

日本人はリスク感覚が希薄だといわれる。日常，マスメディアで報道され る事件や事故に接すると，リスクに対する認識が甘かったのではないかと感 じる例は多々あると思う。

ところで，「リスク」ということばには大きく分けて二つの意味がある。 これまでは損失の発生の可能性というネガティブな意味で使ってきたが，資 産運用の分野では損失と収益のバラツキ度合について「リスク」ということ ばを使う ${ }^{19)}$ 。顧客が資産運用商品を選択するにあたっては，その商品が持つ

19）前掲（注 2 ）の金融庁報告書では, リスクという用語の意味を二とおりに解 説している。同報告書11頁参照。 
消費者教育としての保険教育

リスクを理解しなければならないし，そのために販売者側には販売上の行為 規制 ${ }^{20)}$ が課されている。しかし，このようなリスクも含めて議論を展開す ると混乱するので，本稿では，リスク教育は特に断わり書きのないかぎりは， 自然災害や人的災害を予防する防災や減災を目指す教育あるいは災害発生後 の損失補てんの問題として論述する。

リスク教育については，過去の津波災害の経験が十分には生かされなかっ たことから，東日本大震桨以降その重要性が再考され，国を中心に多角的な 検討が行われている ${ }^{21)}$ 。今回の震災の犠牲者のうち，90\%以上が津波による ものであった。津波から自分の身を守ろうとすれば迅速な避難行動を徽底す るしか方法はないから，普段からの避難行動の教育というソフト面が再認識 された。耐火・耐震, さらには防波堤・防潮堤といったハード対策はこれま でも国を中心に推進され，一定の効果を上げてきたが22)，津波に対するソフ 卜面での対策，すなわち津波に対するリスク教育が䒜緊の課題となっている。 このほか，災害という点では同様の交通事故については，例えば全国で発生 する交通事故の約 $55 \%{ }^{23)}$ が交差点で起こっていることは, リスク教育上は きわめて重要な情報であるといえる。

損保協会では，ライフステージに応じたリスクや損害保険の理解促進の取 組みを行っているが，幼児期・小学生期では，保険の仕組みを理解する前提

20）例えば，「保険業法」，「金融商品の販売に関する法律」，「金融商品取引法」 さらには「消費者契約法」などがある。

21）内閣府の中央防災会議第32回（2012年 9 月 6 日）で報告された「防災対策推 進検討会議」最終報告では，防災教育に関し学習指導要領の見直しなどに言及 (32頁)。文部科学省が2012年 7 月に公表した「東日本大震災を受けた防災教 育・防災管理等に関する有識者会議」最終報告でも, 防災教育の具体的, 系統 的，体系的な指導内容の構築が提言された。

22）例えば，「建築物の耐震改修の促進に関する法律」に基づき耐震改修の促進 が図られていて，学校や病院では耐震化率の数值目標が掲げられている。

23）警察庁が2013年 2 月28日に公表した「平成24年中の交通事故の発生状況」に よれば，市街地・非市街地を合わせた交差点での事故の件数割合は $53.9 \%$ であ る。 
となるリスク教育に重点を置いて実施している。その典型的な取組みが「ぼ うさい探検隊」である。これは小学生がグループごとに自分たちの住んでい る地区を，防災・防犯・交通安全をテーマとして探検し，その結果をマップ

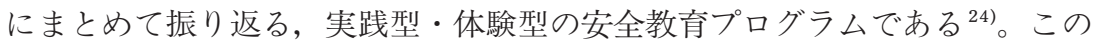
リスク教育の意義は，リスクに対する気づきがこどもを通して親などの大人 に伝播すること，そしてマップ作りを通して地域的な広がりが生まれること である。教育は共有すること，伝播することによってその効果が飛躍的に拡 大する。

\section{6 ．消費者庁，文部科学省および金融庁の取組み}

2012年12月に推進法が施行されたこともあって，消費者教育の議論が消費 者庁や文部科学省で活発化している ${ }^{25)}$ 。特に注目したいのは，推進法に基づ いて内閣総理大臣と文部科学大臣が作成した「消費者教育の推進に関する基 本的な方針」（以下「基本方針」という。）である。2013年 6 月28日に閣議決 定されたものである。この基本方針は，消費者教育推進の意義・必要性，推 進のための基本的な方向, 各実施主体の役割, 学校教育・地域教育・家庭教 育の内容，人材育成，教材のあり方，消費者政策との連携など，総合的・一 体的で，かつ，この問題の奥深さを感じさせる内容が盛りだくさんである。

この基本方針がまとめられた背景には，あるべき消費者像が大きく変わっ てきたということがある。沿革的には2004年に，「消費者保護基本法」から 「消費者基本法」に名称が変更され，単に消費者保護というよりは，「消費者 の権利の尊重」と「消費者の自立の支援」を基本とする消費者政策に改めら

24）損保協会が行っている消費者教育の概要や意義をまとめたものとして，前掲 （注 2 ）で触れた「金融経済教育研究会」の第 2 回会合（2012年11月27日）に おいて損保協会が報告した資料がある（金融庁のホームページから閲覧可能）。

25） 2004年に「消費者保護基本法」が改正され，消費者政策の基本が「保護」か ら「自立支援」に重点が置かれ，消費者の自立を支援するためには消費者教育 を受けられる機会の充実が必要であり，そこで消費者教育の推進の議論になっ た。 
消費者教育としての保険教育

れたことに端を発している。推進法では，その 2 条に「消費者教育」の定義 規定が置かれている。それによれば，消費者教育とは，「消費者の自立を支 援するために行われる消費生活に関する教育（消費者が主体的に「消費者市 民社会」の形成に参画することの重要性について理解及び関心を深女るため の教育を含む。）及びこれに準ずる啓発活動をいう。と規定している。すな わち，知識教育のレベルを超えてかなり広い意味で捉えていることがわかる。 また，「消費者市民社会」については同じく 2 条に定義があり，「自らの消費 生活に関する行動が現在及び将来の世代にわたって内外の社会経済情勢及び 地球環境に影響を及ぼし得るものであることを自覚して，公正かつ持続可能 な社会の形成に積極的に参画する社会をいう。」と規定し，消費者を消費者 市民社会の担い手として育成しようとする意四が明確にされている。知識・ 判断・行動が一体となって，さらにそれらを駆使して持続可能な社会の実現 を担うのが新たな消費者像であり，目標とするところが相当に高水準である ことがわかる。こうした消費者像の変化は, 当然, 我々が行う保険教育にも 大きな影響を与えることになる。

一方，金融分野では，この10余年の間，金融自由化の前提として金融経済 教育の必要性が唱えられ ${ }^{26)}$ ，金融庁内では検討機関を設置して議論を行われ てきた。最近では，前述した金融庁報告書がその成果である。この報告書に よれば金融経済教育の意義をおおよそ下記のとおり整理している ${ }^{27)}$

(1) 金融自由化以降の金融経済教育推進の議論は，2008年の金融危機によっ てその必要性が OECD G20 などの国際的な議論においても共有され，

26） 2000 年 6 月にまとめられた金融審議会答申「21世紀を支える金融の新しい枠 組みについて」では，金融取引ルールの実効性確保の観点から，金融分野にお ける消費者教育の推進が金融 ADRの整備とセットで提言されている。これは 消費者教育と金融 ADR は実は同根であることを物語っている。

27）金融庁報告書では，業界団体・各金融機関等の役割につき，金融経済教育の 推進の重要な担い手であり，積極的な取組みが引き続き期待されるが，「金融 商品の販売推奨との境目が不明確になるおそれがあり，金融経済教育として実 施するものなのか, 個別商品の販売推奨に主眼を置いたものなのかを参加者に 示した上で実施することが望まれる。」としている。同報告書18頁。 
これは「金融リテラシー」の向上という概念で捉えることができる。

(2)「金融リテラシー」とは，より良い暮らしを達成するため，収支を改善 する家計管理や病気・災害, 教育・住宅取得・老後等の生活設計を習慣化 し，各生活設計に合わせて金融商品を適切に利用選択する知識・判断力を 身に付けることをいう。換言すれば，生活する力（生活スキルとしての金 融リテラシー）を身に付けることをいう。

消費者教育をめぐる消費者庁・文部科学省の動きとこの金融庁の動きは, それぞれにフィールドや法制度を異にするところはあるが，前述の基本方針 がまとめられたことによりその関係は明確になった。基本方針では，「金融 リテラシーは，自立した消費生活を営む上で，必要不可欠であり，消費者教 育の重要な要素であることから，金融経済教育の内容を消費者教育の内容に 盛り込むとともに，金融経済教育と連携した消費者教育を推進することが重 要である。」と記載された。また，今後の金融経済教育の推進役となる金融 広報中央委員会の「金融経済教育推進会議」には，有識者，関係団体のほか， 金融庁はもちろん，消費者庁と文部科学省もメンバーとして参画している。

\section{7.おわりに}

これまで，損害保険の消費者教育としての保険教育について，損保協会の 取組みを中心にして，行政の動きを交えながら考察したが，畢竟，消費者に 対する保険教育が業界団体にとって，ますます重要なミッションになってき たことが明らかになった ${ }^{28)}$ 。もちろん，個社の取組みを否定するものではな いが，非営利の業界団体の方が取り組みやすいという面は否めないだろう。

消費者教育の推進が推進法という新たな法律に基づいて総合的・一体的に 行われようとしているときに，あらためて保険教育の意義や課題を考えてみ る価值は大いにあると思う。おわりに，いくつかの点を指摘することで本稿

28）欧米の保険業界団体の消費者向け保険教育の取組みについては，損保総研 『欧米における消費者保護に向けた保険教育・情報提供および相談・苦情対応』 （2007年）がある。 
消費者教育としての保険教育

のまとめとしたい。

第一は，消費者教育というとてつもない広大な分野のごく一部が金融経済 教育の分野であり，さらには損害保険教育の分野は金融経済教育のごく一部 に限られていることを，我々損保業界はどのように認識すべきかということ である。前述したように，基本方針は，消費者教育における金融経済教育の 位置づけを明確にしたことから，損害保険については，消費者教育の推進と いう大きな流れに沿いながら，当面は，金融経済教育の一環として捉えてい くことになる。このオールジャパンと金融の関係は，あたかも「裁判外紛争 解決手続の利用の促進に関する法律」と金融 ADR 制度の関係に似ている。 金融分野をことさらに分ける理由は，その専門性と複雑性 ${ }^{29)}$, そしていわゆ る業法で規制されている業種なので主務官庁の権限が強いことである。では， 損害保険を金融経済教育のなかでどう位置づけていくのかについては，さま ざまな金融商品があるなかでは，損害保険を突出して取り上げるのは現実的 ではないだろう。ただし，消費者が金融商品を購入する目的によって分類す ると，損害保険とその他の金融商品の間では大きな違いがあることが明らか になる。それは, すなわち, 機能の違いであり, 資産保全か資産形成かの違 いである。損害保険は資産保全がその機能であり，積立型の損害保険を除け ば，直接的には資産形成の機能はない。一方，その他の金融商品は資産保全 （貯蓄がその典型である。）と資産形成の双方の機能を有しているものが多い。 この機能の違いを消費者に理解してもらう教育は，最低限，金融経済教育に おいては必要である30)。そして，なぜ資産保全が必要かということがリスク

29）金融庁報告書では，金融分野の「専門性・複雑性」をその特徵として挙げて いる。同報告書 8 頁，10頁，14頁。

30）機能や特徵が異なるさまざまな金融商品について金融経済教育を行おうとす れば，消費者に対してまず，それぞれの違いを理解してもらう必要がある。こ の総論部分の教育は重要である。「リスク」ということばの使い方も，資産運 用用語としての理解だけでは，おそらく保険の理解を妨げる。逆も然りである。 損害保険を「掛け捨て」と表現する発想も「リスク」の使い方，理解の仕方か ら生じている。 
教育につながっていく。また，損害保険のなかの責任保険に該当する分野は， 例之ば，自動車保険（対人・対物賠償）や自転車事故に係る責任保険に代表 されるように「被害者」を救済する最有力手段として利用される。この点も 資産保全機能ではあるが一般の金融商品とは異なるところであり，金融庁報 告書で述べられたような金融経済教育か金融商品の販売推奨かの峻別がしに くい保険商品があることに留意する必要がある。

第二は，金融経済教育のなかでは損害保険のみに焦点を当てた消費者向け の保険教育が難しいということであれば，前述した大学での保険教育はこれ を補完する絶好のフィールドであるということである。消費者または消費者 予備軍である学生に対して，理論教育と実務教育の双方を行うことができる， またとない学習機会を提供できる ${ }^{31}$ 。我が国における大学（短大を含む。） の進学率は55\%程度であり ${ }^{32)}$ ，しかも保険講座を有している大学はそう多く はないので，保険教育の定着というほどの大きな広がりは期待できない。し かし，金融講座というくくりで考えれば，さらに広がるであろうし，すでに 損保協会が提供する寄附講座でも例があるとおり，教養課程で開設すれば受 講学生をさらに増やすことができる。例えば, 自治体の広報誌を使って消費 者講座の開催を情宣しても，筆者の経験では，たくさんの参加者は期待でき ないし，まして働き盛りの層を大勢集めることは相当困難である。それに比 べれば，大学教育については，対象は大学生という層に限られるが，授業の 一環であるから一定の受講者を確保でき，かつ，連続して学べるメリットは

31）推進法では，第 3 条（基本理念）において「消費者教育は，消費生活に関す る知識を修得し，これを適切な行動に結び付けることができる実践的な能力が 育まれることを旨として行われなければならない。」と定めている。実践的な 能力を育むのが実務教育である。

32）文部科学省が2013年 8 月に公表した「平成25年度学校基本調查（速報值）」 では，大学・短大進学率は，現役，浪人を合わせて $55.1 \%$ であるなお，同省 がホームページ上で公表している「高等学校教育の現状」では，定時制を含め た高等学校進学率は $98 \%$ である。ただし, 学生数・生徒数で比較すると, 上記 速報值では，大学生・短大生は約 300 万人，高校生は約 330 万人であり，人数に 大きな差はない。 
消費者教育としての保険教育

大きい。筆者が知るかぎりでは受講学生が300名という保険講座もある ${ }^{33)}$ 。

第三は，消費者側の学ぼうというインセンティブをどのように喚起するの かということである。消費者と事業者の情報の非対称性を埋めるために，消 費者教育の機会をライフステージごとに，あるいは実施主体ごとにいかに提 供しても，消費者が学ぼうという姿勢や行動を持ななければ実効性はない。 消費者教育が抱えるいちばんの困難な課題はこの点かもしれない。消費者の 自己責任を問われるからといって，インセンティブが容易に高まるわけでも なく，契約理論に基づく権利と義務の関係を粘り強く，繰り返し説明するほ かはないのだろう。検定制度を設けてはどうかという意見もあるようだが， そのメリットを誰もが実感できないと奏効しない。なお，消費者の努力義務 を法定した例として以下があり，改めてこの問題の消費者側の原点として示 しておきたい。

（1）消費者契約法 3 条（事業者及び消費者の努力） 2 項

消費者は，消費者契約を締結するに際しては，事業者から提供され た情報を活用し，消費者の権利義務その他の消費者契約の内容につい て理解するよう努めるものとする。

(2) 消費者基本法 7 条

消費者は，自ら進んで，その消費生活に関して，必要な知識を修得 し，及び必要な情報を収集する等自主的かつ合理的に行動するよう努 めなければならない。(以下略)

第四は，そもそも消費者教育の意義は何かということである。前述の基本 方針では，消費者教育を「被害に遭わない消費者，合理的意思決定ができる 自立した消費者にとどまらず，社会の一員として，よりよい市場とよりよい 社会の発展のために積極的に関与する消費者を育成する教育を意味する。」 ${ }^{34}$

33）これから社会人をめざす大学生には，保険を購入する消費者という立場のほ かに，保険代理店として保険を販売する募集人の立場もあることに留意する必 要がある。自動車販売や銀行へ勤めればほぼ100\%は募集人として保険を販売 する側に立つ。まさに社会勉強という位置づけもある。

34）基本方針 8 頁。 
と記述している。しかし，こうした消費者像を追い求めようとすれば，消費 者教育にはその主体・客体の論議を前提にするべきではないことになる。消 費者を消費者教育の客体として位置づけるかぎり，受身的な姿勢を超えるこ とはできないということだろう ${ }^{35)}$ 。一方，事業者側も教えるだけでは事業の 持続的発展はない。お互いが学びあう，お互いが教えあうという発想が必要 である。実は，保険金不払問題以降，各保険会社はすでにこの発想を取り入 れているはずである。「消費者の声」を聞くことは，消費者とのコミュニケ ーションを推進することであり，それは消費者との接触を一層増やして学び あい，より高い次元での関係を築いていく，いわば広義の消費者教育が前提 のなかで成り立つものである。消費者教育の意義も, 時代とともにさらに進 化し続けていることに，社会全体が関心を持たなければならない。

第五は，きわめて実務的な問題であるが，保険教育の前提として，使用す る用語については業界用語や誤解を招きやすい用語は極力排除すべきだとい うことである ${ }^{36)}$ 。どうしても業界用語を使う必要があるならば合理的な説明 ができなければならないし，業界用語を一般用語に定着させる不断の努力が 必要である。もともと保険商品は一般の金融商品に比べても複雑なところが あり，商品がわかりやすいこと，説明がわかりやすいこと，そしてそのよう な情報を容易に入手できる体制を整えることは必須であるが，そのとっかか りが用語の使い方である。すでに業界ベースや個社ベースで取り組まれてい るが37)，さらなる改善が期待される。例えば，フリート・ノンフリート（自 動車保険の契約方式を表す用語だが，一般消費者にはまったく見当もつかな

35）基本方針では，消費者の自覚の喚起として，「消費者市民社会の形成に重要 な役割を担う消費者は，消費者教育の客体であるにとどまらず」と記述してい る。30頁参照。

36）基本方針では，消費者教育の担い手としての事業者・事業者団体に対して， 「専門用語や業界用語などを用いずに，一般の消費者に分かりやすく物事を説 明する能力の育成」を期待している。30頁参照。

37）保険約款と保険商品のわかりやす巳（用語の見直しを含む。）についての業 界の検討状況や改定例は, 竹井直樹・柴田文明「保険約款と保険商品のわかり やすさの向上について」損害保険研究第72巻第 2 号115頁 123頁 (2010) 
消費者教育としての保険教育

い。），火災保険（現在の補償範囲を考えれば，誤解を招く用語になっている。 歴史用語と位置づけ，「すまい保険」など，業界統一用語の使用が望まれ る。），借家人賠償責任保険（賠償責任なら何でも補償するように読め，大家 向けであることが理解されにくい。）などがある。

第六は，己れも実務的な問題であり，かつ，消費者教育に限ったものでは ないが，教え方の問題である。相談員向けの勉強会では，事例を中心に学び たいという要望がしばしば寄せられる。理解しやすく, 即効の知識が得られ るということがその理由であろう。いわゆるハウツー教育である。こうした 教え方, 学び方は, 推進法に定める「適切な行動に結び付けることができる 実践的な能力が育まれること」にはならないと思う。基本が最初にあって， それを踏まえて事例があるのであって，事例だけ学んでも応用問題は解けな い。もちろん話の組み立て方の問題はあるが，「保険はむずかしい」からこ そ，何故かということを問いかける保険教育を基本に据えるべきである。

損保業界がこれからも持続可能な発展を続けていくためには，消費者の意 識を高める努力をしながら消費者を味方につけるマインドを持ってビジネス モデルを構築していく必要がある。これは，時間もかかるし，簡単に実現で きるものではないが，前述した新なな消費者像を見据えて，保険会社と消費 者がともに学びあう教育環境やコミュニケーション環境を築きながら，進化 した新なな時代を創らなければならないということだと思う。

(筆者は日本損害保険協会勤務) 